\title{
The Influence of Dulohupa Method on Community Empowerment
}

\author{
${ }^{1}$ Universitas Negeri Gorontalo, Gorontalo, Indonesia \\ *Email: abdulrahmat@ung.ac.id
}

Abdul Rahmat ${ }^{1, *}$

\begin{abstract}
This study examines the effect of the dulohupa method on community empowerment in Gorontalo Province. The purpose of the study is to test the hypothesis of Dulohupa method on community empowerment. The method used is an experimental method one group pretest-posttest design. A sample of 36 people. Normality test using Lilliefors Test and obtained L0 value $<$ Ltable that is in pretestL 0 value $=0.138$ and posttestL0 value $=0.096$ while for Ltable value $=0.149$ data the results of this study indicate that for pretest and post data test is normally distributed. Homogeneity of the Barlett test variance chi squared statistics obtained 0.983 $<3.841$ then the data is homogeneous, this test aims to determine the hypothesis test technique to be used because the homogeneous hypothesis test used is the $t$ test statistic. From the results of hypothesis testing obtained $t$ count $>t$ table that is $t$ count $=5.68$ and $t$ table $=1.67$. Thus it can be concluded that there are significant differences from community empowerment before and after the dulohupa treatment or method. With these differences, it can be concluded that there is an influence of the dulohupa method on community empowerment.
\end{abstract}

Keywords: dulohupa method, community empowerment, learning

\section{INTRODUCTION}

It's not easy to serve people who have different backgrounds, different social societies, different cultures and levels of education. Need extra patience. Sometimes we have the intention to be advocated for suspicion, or even terrorized and others. They will be aware and understand what our intentions and goals are if what we do is reaping the results. If it is only the beginning stage there are usually many obstacles that come from within the community itself. The parties concerned not only supporters but also opponents. Everything can be measured by the level of support and against it. How far does he support and oppose? Is it up to the level of harm if this opponent does not accommodate his opinion? Or is it just limited to opposing it without any supporting power that can be ignored? When we realize the meaning of empowerment, there are many programs related to empowerment issues. Various problems arise related to empowerment issues, from the issue of women's empowerment, issues of empowerment of residents of forests around the interior of Kalimantan and West Papua, empowerment issues related to reproductive health, education issues, gender equality issues, economic, social, cultural and political empowerment issues, global warming and others. Problems that are so complex cannot be solved in general without involving all the potential that exists in the community. However, this does not mean that the empowerment problem cannot be resolved.

The new framework, commonly referred to as the "new paradigm" of community empowerment in question, is characterized by several important aspects concerning the problem: debure aucratization, participation, privatization, transparency, accountability, decentralization, and empowerment that rely on strengthening local communities, increasing life aspirations, programs large scale, integralistic program, involving women, and the use of local organizations. These principles must be understood by all planners, actors and beneficiaries of the project itself, starting with the government, the private sector and the community.

Based on the thoughts made by the three poverty approach groups (cultural approach by Oscar Lewis 1966, situational approach by Charles A. Valentine 1968, and the interactional approach by Herbert J. Gans 1968) in Sudiarta \& Suardana[1], it was alleged that the opportunity to succeed in poverty alleviation programs and community empowerment, will be greater if the poor or target group communities are given greater opportunities to take care of themselves, to influence decisions, and participate in activities that affect economic capacity and welfare and empowerment of their lives. The role of the government as far as possible is limited to efforts to realize the will of the community, provision of funds and infrastructure.

In this case the government or project parties must actively involve local organizations and make local organizations as work partners. Local organizations in any form (BKM/KSM/Koperasi/KUB/Association and the like) must be motivated and guided and directed towards an independent form of community power, which is free from dependence on outside institutions. Local organizations must in turn play a role and function to replace external institutions, and in no way must make local organizations 
dependent on outside institutions. Forms of coaching that ultimately make the dependence of local organizations to external institutions, the program has come out of the corridor of empowerment and independence.

One culture that is still being developed in the Gorontalo community is deliberation or in their language (dulohupa). They view deliberation as one of the things that is very important for life, not only in the life of the nation and state but in domestic life and economic development. The meeting was considered important, among other things because deliberation was one of the tools that was able to associate them as one of the means to gather or seek more and good opinions. For example, the conflict between the people and the head of the hamlet, sometimes this conflict occurs because of different levels of understanding. Parents who have low education, sometimes wrong in carrying out the regulations of the hamlet mandated to him.

For the people of Gorontalo, meeting people are the unifying symbol of the people to always trust and assume good faith towards each other. In it there are values of togetherness, equality, equality and respect for human dignity, dignity and degree. These values are the inspiration for people's deliberations. Therefore, in people's deliberations, realizing that each individual is part of another person becomes important to everyone. So that differences of opinion become beautiful and a sign of progress. With differences, everyone will increasingly try to gather and seek fulfillment ties that can be jointly and harmoniously received and carried out jointly by community members [2].

Deliberation is a legacy that has taken root in a sociocultural way in the community of nations in Indonesia. Not surprisingly, then the founders of this nation stated and believed, the essence of democracy and Indonesian ideology was deliberation. The long trajectory of the history of this nation's community has proven that people's deliberation is a great force as the language of people's lives.

Deliberation is a source of strength in enlightening and fighting for the independence of the life of the nation, because deliberation teaches critical awareness, togetherness and justice [3]. The Gorontalo language conference is dulohupa which is a dynamic culture. That is, dulohupa (meeting) changes and develops, because basically a culture such as deliberation, grows from the life experiences of community members as the main subjects or actors. And because the experiences of these communities are different, diverse and developing, the idea of deliberation as culture in itself also contains very large and great dynamics. But the culture of deliberation is increasingly eroded day by day from the survival of life in the Indonesian community of clans, tribes, and peoples. The task for all of us is to jointly defend and save, and enlighten and renew the culture of people's deliberations. [4]

The learning of dulohupa today is being developed in learning. This can be seen from the inclusion of local content expected during the process and the end of the learning in the Learning Implementation Plan (RPP).
However, in reality this has not been fully realized. Almost in all schools it was found that the learning pattern was still product-oriented, in this case learning outcomes especially cognitively. Learning outcomes are only obtained from written tests. Assessment of the affective and psychomotor aspects of students is still poorly applied.[5]

The learning process that is organized interactively, inspiratively, fun, challenging, motivates students to actively participate and provides sufficient space for initiative, creativity, and independence in accordance with the talents, interests, and physical and psychological development of students. If an active and creative learning atmosphere occurs, it will encourage students to like and motivate them to continue learning. Active, creative and fun learning activities must still rely on the goals or competencies to be achieved. In this way, it will be easier for the teacher to instill the expected characters in students. The closeness and openness that was built during the learning process using the dulohupa approach is expected to be the main key in learning for illiterate people. Thus, it is expected that the application of dulohupa learning can present an effective learning model especially for illiterate learning.[6]

This research can be a vehicle for innovation in education, especially in Gorontalo Province. Consultation education (dulohupa) is not only a discourse in the world of education, but vice versa. With the production of a dulohupa learning model, it will be able to present education in the classroom properly. This learning model will pass several feasibility tests so that it can indirectly know the effectiveness of its use in learning.

\section{RESEARCH METHODS}

This research was conducted in the province of Gorontalo. The method used is the experimental method. According to Kuswanto[7] "research with an experimental approach is a study that seeks to influence the influence of certain variables on other variables, under tightly controlled conditions". Because this study uses only one group of subjects and take measurements before and after treatment then this study design using one-group pretest-posttest design. The difference in results before and after the treatment of the subject is the effect of the treatment, it can be systematically described as follows:

\section{$\mathrm{O}_{1} \mathrm{X} \quad \mathbf{O}_{2}$}

\section{Figure 1 Research Design}

$$
\begin{array}{ll}
\text { Information: } & \\
\text { O } 1= & \text { Pretest Value (before treatment) } \\
\text { O } 2= & \text { Posttest value (after treatment) } \\
\mathrm{X}= & \text { Application of the dulohupa method } \\
\text { (O 2 -O1) }= & \text { The influence of dulohupa method }
\end{array}
$$

According Sugiyono population is generalization region comprising a bag objek/subjek that has certain qualities and characteristics defined by the researchers to learn and 
then drawn conclusions [8]. Based on this understanding, the population in this study is 36 people. Because the population is less than 100 , in this study the sample is the total number of population, which is 36 people. Data collection techniques use techniques through treatment and documentation. Validity is a measure that shows the level of validity or validity of an instrument [9]. For that before the instrument is used the researcher first tested the validity so that it can actually be used. to measure data on research. The validity of the instrument in this study uses the Product Moment formula as follows:

$$
r_{x y}=\frac{n \sum X Y-Q X X(2 Y)}{\sqrt{\left(n \sum X^{2}-\left(\sum X\right)^{2}\right) \cdot\left(n \sum Y^{2}-\left(\sum Y\right)^{2}\right)}}
$$

Figure 2 Product Moment Formula[10]

$$
\begin{aligned}
& \text { Information: } \\
& \text { rxy }=\text { Correlation coefficient } \\
& \mathrm{X}=\text { Score item item } \\
& \mathrm{Y}=\text { Total number of scores for each question } \\
& \mathrm{N}=\text { Number of respondents }
\end{aligned}
$$

The instrument used in the study must be tested for its validity and reliability. According to Sugiyono instruments that are not tested for validity and reliability when used for research will produce data that is hard to believe the truth [11]. Thus the instrument reliability testing in this study uses the Alpha Cronbach formula, namely:

$$
r_{11}=\left[\frac{k}{k-1}\right]\left[1-\frac{\sum \sigma b^{2}}{\sigma t^{2}}\right] r
$$

Figure 3 Rum Alpha Cronbach[10]

Information:

$r_{11}=$ Rally a Bilitas test

$\mathrm{k} \quad=$ Number of questions

$\sum \sigma b^{2}=$ Number of variance scores for each item $\sigma t^{2}=$ Total variance

Testing the normality of data from research results obtained whether normal distribution or not normally distributed, can use statistical testing Liliefors test [9] with the equation:

$$
z=\frac{x-\bar{x}}{s}
$$

Figure 4 Liliefors test

With the criteria of normality, that is if Lmax $<$ Ltable then the data berdist $r$ i normal plugs.

This homogeneity test aims to find out the uniformity of the class before using the Dulohupa method and the class after using the Dulohupa method. Homogeneity in this study uses the Barlett test [12]

$$
\chi_{\text {hitung }}^{2}=(\ln 10)\left\{B-\Sigma(n i-1) \log S_{1}^{2}\right\}
$$

Figure 5 Barlett ice T test

$$
\begin{array}{ll}
\text { Information: } & \\
\mathrm{C} & =\text { Sample Size } \\
\mathrm{B} & =(\text { Log } \mathrm{S}) \times \Sigma(\mathrm{n}-1) \\
\log S_{1}^{2} & =\text { Variance } \\
\mathrm{i} & =\text { Express class. }
\end{array}
$$

The homogeneity test of variance in this study is based on the statistical hypothesis as follows:

Ho $=\sigma 12=\sigma 22$ : Population has homogeneous variance

$\mathrm{Ha}=\sigma 12 \neq \sigma 22:$ Population with non-homogeneous variance

The testing criteria are for the real level $\alpha=0.05$ reject the Hojika hypothesis $\mathrm{x} 2>\mathrm{x}(1-\alpha)(\mathrm{k}-1)$, in other cases Haditerima[13].

\section{RESULTS AND DISCUSSION}

\subsection{Instrument Validity Test Results}

The instruments in this study have been tested for validity and reliability before being used in the field. Good instruments for variable $\mathrm{X}$ (dulohupa method), as well as instruments for variable $\mathrm{Y}$ (community empowerment). The results of testing the validity and reliability of the two variables are as follows.

Variable X Validity Test Results (dulohupa method)

The category of instrument validity which refers to the classification of validity presented by Riyani, Maizora, \& Hanifah[14] quoted in the UPI Journal are as follow 
Table 1 Classification of validity coefficient interpretation

\begin{tabular}{|l|l|}
\hline \multicolumn{1}{|c|}{ Validity Coefficient } & \multicolumn{1}{c|}{ Information } \\
\hline $0.90 \leq \mathrm{r}$ xy 001.00 & Very high validity (very good) \\
\hline $0.70 \leq \mathrm{r}$ xy $\leq 0.90$ & High validity (good) \\
\hline $0.40 \leq \mathrm{r}$ xy $\leq 0.70$ & Medium validity (enough) \\
\hline $0.20 \leq \mathrm{r}$ xy $\leq 0.40$ & Low validity (less) \\
\hline $0.00 \leq \mathrm{r}$ xy $\leq 0.20$ & Very low validity (very lacking) \\
\hline $\mathrm{r} x y \leq 0.00$ & Invalid \\
\hline
\end{tabular}

From the table 12 classification interpretation validity coefficient, obtained 20 items in the instrument variable $\mathrm{X}$ (method dulohupa) the validity coefficient. From the results of the analysis of 20 instrument items of variable $\mathrm{X}$, 14 valid instrument items and 6 invalid instrument items were obtained. This is because the instrument item is said to be valid if $r$ count $>$ rtable, and invalid if $r$ count $<r$ table.

Validi bag test results and $\mathrm{Y}$ variable (community empowerment)

The category of instrument validity refers to the classification of validity presented by Riyani et al[14] quoted in the UPI Journal on page 6 as well as in the second place classification of the interpretation of the validity coefficient, 10 assessment items were obtained in the variable $\mathrm{Y}$ instrument (community empowerment) the coefficient of validity. From the results of the analysis, obtained 10 items of assessment of community empowerment it is valid, in other words all items are valid. The validity of the validity of the 10 assessment items is declared valid. Because matter or assessment items considered valid if $r$ count $>r$ table, and invalid if count $r$ $<\mathrm{r}$ table.

\subsection{Reliability Test Results}

As in the validity test for variable $\mathrm{X}$ (dulohupa method), the reliability test is also done, such as instrument variable Y (community empowerment). The results of the reliability testing of the two variables are as follows.

Variable Reliability Test Results X (dulohupa method)

Referring to the question reliability classification according to Guilford [15] as quoted in the UPI journal as follows.

Table 2 Test reliability classification

\begin{tabular}{|c|c|}
\hline Correlation Coefficient & Interpretation \\
\hline $0.80 \leq \mathrm{r} 11001.00$ & Very high reliability \\
\hline $0.60 \leq \mathrm{r} 11 \leq 0.80$ & High reliability \\
\hline $0.40 \leq \mathrm{r} 11 \leq 0.60$ & Medium reliability \\
\hline $0.20 \leq \mathrm{r} 11 \leq 0.40$ & Low reliability \\
\hline $\mathrm{r} 11 \leq 0.20$ & Very low reliability \\
\hline
\end{tabular}

From the resulting distribution of validity and reliability tests, obtained reliability of the test for the variable $\mathrm{X}$ (method dulohupa) r $11=1,037$.Thus it can be concluded that reliable test instruments have very high interpretations and can be used as data collectors in this study.

Variable Reliability Test Results Y (community empowerment)
Referring to the question reliability classification, as table 3 test reliability classification, the reliability of the Y variable (community empowerment) test $r 11=0.997$ was obtained. Thus it can be concluded that reliable assessment test instruments have very high interpretations and can be used as data collectors in this study. 
accepted cause $L_{0}<L_{\text {tabel }}$. This means that the data is normally distributed.

\subsubsection{Testing Normality of Post Test Data}

As for testing the normality of pre-test data, testing the normality of post-test data is also based on the results of community empowerment data from a sample of 36 children with a significant level $a=0.05$ obtained value $L_{0}$ amounting to 0.096 and for value $L_{\text {tabel }}$ amounting to 0.149 . Thus it can be concluded that the hypothesis $H_{0}$ accepted cause $L_{0}<L_{\text {tabel }}$. This means that the data is normally distributed.

The calculation results from the normality test can be seen in table 3 below.

Table 3 Results of data normality tests

\begin{tabular}{|l|l|l|l|}
\hline \multirow{2}{*}{$\begin{array}{l}\text { Data } \\
\text { Source }\end{array}$} & & & \multirow{2}{*}{ Conclusion } \\
\cline { 3 - 3 } & & 0.05 & \\
\hline Pre test & 0.138 & 0.149 & Normal \\
\hline Post test & 0.096 & 0.149 & Normal \\
\hline
\end{tabular}

Based on the results of testing the data from both data, the results showed that the two data were normally distributed, so that the hypothesis testing used parametric statistical tests.
Based on the calculation results obtained value $^{X^{2}}$ hitung $=0.983$ while the value $=3.841$, it can be concluded that the data comes from a homogeneous population.

\subsubsection{Data Homogeneity Test Results}

Table 4 Homogeneity test results

\begin{tabular}{|c|c|c|c|}
\hline Data / Source & & & Conclusion \\
\cline { 1 - 2 } Pre test & 0.983 & 3,841 & Homogeneous \\
\hline Post test & \multirow{2}{*}{0} & & \\
\hline
\end{tabular}

This homogeneity test aims to determine the hypothesis testing technique that will be used. Because the data is homogeneous, the hypothesis test used is the t-test test statistic.

\subsubsection{Description of Community Empowerment on Pre Test and Post Test}

The description of community empowerment in this study can be seen in the form of mean (M), median (Me), Mode (Mo), standard deviation (St. Dev), and variance $\left(\mathrm{S}^{2}\right)$, frequency distribution and bar diagrams as shown in the following table. 
Table 5 Description of research data

\begin{tabular}{|c|c|c|}
\hline Statistics & Pre Test & Post Test \\
\hline Sample size & 36 & 36 \\
Min & 21 & 25 \\
Max & 32 & 36 \\
Average & 25.89 & 31.06 \\
Mode & 24.2 & 31.3 \\
Median & 25,28 & 31.5 \\
Standard Deviation & 3,442 & 2,971 \\
\hline
\end{tabular}

Descriptive of Community Empowerment Before Using Dulohupa Method (pretest)

Learning residents who take lessons before using dulohupa method is 36 people. The minimum score obtained by this group is 21 and the maximum score is 32 . The average score is calculated $(\bar{X})$ ) obtained after grouped data is 25.89 , mode (Mo) is 24.2 , median (Me) is 25.28 , and the standard deviation is 3.442.Community empowerment data before using the dulohupa method can be seen in table 4.16 frequency distribution below.

Table 6 List of frequency distribution of community empowerment pre test

\begin{tabular}{|c|c|c|c|}
\hline No. & Interval Class & Absolute Frequency & $\begin{array}{c}\text { Relative Frequency } \\
(\%)\end{array}$ \\
\hline 1 & $20-21$ & 3 & $8.3 \%$ \\
\hline 2 & $22-23$ & 7 & $19.4 \%$ \\
\hline 3 & $24-25$ & 9 & $25.0 \%$ \\
\hline 4 & $26-27$ & 5 & $13.9 \%$ \\
\hline 5 & $28-29$ & 5 & $13.9 \%$ \\
\hline 6 & $30-31$ & 5 & $13.9 \%$ \\
\hline 7 & $32-33$ & 2 & $5.6 \%$ \\
\hline & amount & 36 & 100 \\
\hline
\end{tabular}

Table 6 shows that there are 9 children or $25 \%$ who get around the average value (average value 25,89), there were 10 children or $27.8 \%$ scored lower than the average score, and 17 children or $47.2 \%$ obtained higher than the average score.

The distribution of data in the frequency distribution table above can be described in the form of a bar diagram below:

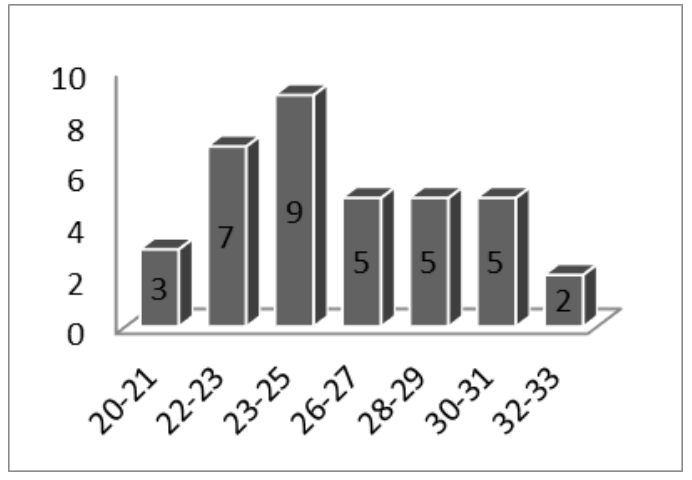

Figure 6 Stem diagram score of the pre test results 


\subsubsection{Descriptive of Community Empowerment After Using the Dulohupa Method (posttest)}

There were 36 groups of children who took part in learning after using the dulohupa method. The minimum score obtained by this group was 25 and the maximum score was 36. The average score was calculated $(\bar{X})$ obtained after grouped data is 31.06 , mode (Mo) is 31.5 , median (Me) is 31.3 and standard deviation is 2.971.Data on empowering children after using the Dulohupa method can be seen in table 8 of the following frequency distribution.

Table 7 List of frequency distributions for the empowerment of children in the post test

\begin{tabular}{|c|c|c|c|}
\hline No. & Interval Class & Absolute Frequency & $\begin{array}{c}\text { Relative Frequency } \\
(\boldsymbol{\%})\end{array}$ \\
\hline 1 & $24-25$ & 1 & 2.8 \\
\hline 2 & $26-27$ & 5 & 13,9 \\
\hline 3 & $28-29$ & 3 & 8.3 \\
\hline 4 & $30-31$ & 10 & 27.8 \\
\hline 5 & $32-33$ & 10 & 27.8 \\
\hline 6 & $34-35$ & 5 & 13,9 \\
\hline 7 & $36-37$ & 2 & 5.6 \\
\hline & amount & 36 & 100 \\
\hline
\end{tabular}

Table 7 shows that there are 10 students or $27.8 \%$ who get around the average value (mean value 31.06), there are 9 students or $25 \%$ get a score lower than the average value, and 17 students or $47.2 \%$ obtained a value higher than the average value. The distribution of data in the frequency distribution table above can be described in the form of a bar diagram below:

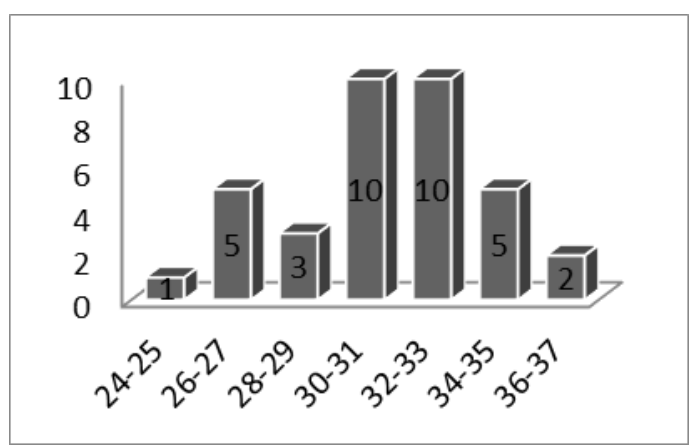

Figure 8 The bar diagram scores the results of the Post Test

\subsubsection{Research Hypothesis Test Results}

Based on the results of testing hypotheses that use the statistical test formula obtained the average results of community empowerment in the pre-test is 25.89 and the average result of community empowerment after treatment or post-test is 31.05.The difference in community empowerment between before and after the treatment was expressed as a significant level, namely $\alpha=0.05$.
From the calculation in the attachment, the value is obtained $t_{\text {count }}$ amounting to 5.68. From the distribution list $\mathrm{t}$ table is obtained $t_{(70: 0,95)}=1.67$. By comparing prices $t_{\text {table }}$ and then obtained $t_{\text {count }}>t_{\text {table }}$. That means $t_{\text {count }}$ in the rejection area $H_{0}$ therefore $H_{l}$ it was accepted and concluded that there were significant differences between community empowerment before and after the dulohupa method was given. The difference showed the influence of the dulohupa method on community empowerment, so the hypothesis that the dulohupa method influenced community empowerment was accepted.

From the above results it is obtained that $H_{0}$ rejected and $H_{l}$ accepted, so it can be concluded that there are significant differences between community empowerment before and after being given the Dulohupa method. After being given the treatment in the form of dulohupa method in posttest it was seen that community empowerment experienced a significant difference. This is shown from the results of the $t$ test obtained by numerical results $t$ count $=5.68$ and $t$ table $=1.67$, meaning that $t$ count $>t$ table means that $\mathrm{H} 1$ is accepted by $\mathrm{H} 0$ is rejected then there are differences in community empowerment before and after treatment or dulohupa method.

Based on the results of hypothesis analysis, it shows that there are differences in community empowerment before and after treatment using the dulohupa method as a treatment. The existence of differences in the results of experimental tests proves that the dulohupa method can influence community empowerment. Dulohupa method is not just telling a story (carlota) but no technic and procedures in practice. This method has many advantages including training concentration to be longer than before, learning citizens can imagine, increase information and so on. According to Dhieni et al [16] the advantages of the 
Dulohupa method are that children are trained to concentrate on learning, learning citizens become good listeners, citizens learn to fantasize about unreal objects, learners learn to listen and read about what is being demonstrated, and learners remember what the tutor told. Therefore the dulohupa method is effective for stimulating community empowerment.

In this study, the average community empowerment before being given treatment or method of dulohupa is 225.89 while the average community empowerment after being given treatment or dulohupa method, which is 36.05 also proves that community empowerment increases after the dulohupa method is given. Community empowerment is one aspect of language development, community empowerment can be the basis for learning to discuss, for this ability is very important to develop.

Through this research, community empowerment can be maximized, so that learning objectives can be achieved effectively and efficiently. With this research tutors can pay attention to every learning method that will be used to stimulate learning citizens.From the explanation above, it can be concluded that the application of the dulohupa method is very effective in stimulating the empowerment of children to be more optimal.

\section{CONCLUSION}

There is a significant difference between community empowerment before treatment and community empowerment after treatment. This can be proven by the average pre test score of 25.89 and the average post test score of 31.05 and the hi potency test that uses the $t$ test which explains that the numerical price $t$ count $=5.68$ and $\mathrm{t}$ table $=1.67$. This means that ( $\mathrm{t}$ count $>\mathrm{t}$ table) the null hypothesis is rejected and $\mathrm{H} 1$ is accepted. Community empowerment after giving treatment (post test) is higher than before treatment (pre test).And for the total score of the pre test is 932 and the total post test score is 1118 , the research hypothesis can be stated that there is an influence of the dulohupa method on community empowerment.

\section{SUGGESTION}

Tutors are expected to consider the strategy of implementing the dulohupa method to be an alternative in the learning process especially for community empowerment. Because through the application of the dulohupa method various aspects of development, especially aspects of language development, can be stimulated. A tutor is expected to be able to properly implement the dulohupa method in the learning process, because dulohupa can stimulate community empowerment and various other aspects of development.

\section{REFERENCES}

$$
\text { I. N. Sudiarta and I. W. Suardana, "Dampak }
$$

Pariwisata terhadap Kemiskinan di Kawasan Pariwisata di Bali,” J. Kaji. Bali, vol. 6, no. 2, pp. 209-227, 2016.

[2] Syaripulloh, "Kebersamaan dalam Perbedaan: Studi Kasus Masyarakat Cigugur, Kabupaten Kunuingan, Jwa Barat," Sosio Didakt., vol. 1, no. 1, pp. 65-78, 2014.

[3] S. Murhaini, "Pemilihan Umum Legislatif sebagai Refleksi Sistem Pemerintahan Demokrasi," J. Konstitus, vol. 1, no. 1, pp. 8-115, 2008.

[4] Y. E. Pratiwi and Sunarso, "Peranan Musyawarah Mufakat (Bubalah) dalam Membentuk Iklim Akademik Positif di Prodi PPKN FKIP UNILA," Sosiohumaniora, vol. 20, no. 3, pp. 199-206, 2018.

[5] F. Azmi, S. Halimah, and N. Pohan, "Pelaksanaan Pembimbingan Belajar Aspek Kognitif, Afektif, dan Psikomotorik Siswa di Madrasah Ibtidaiyah Swasta Amal Shaleh Medan," At-Tazakki, vol. 1, no. 1, pp. 15-28, 2017.

[6] Mariyono, "Strategi Pemberantasan Buta Aksara Melalui Penggunaan Teknik Metastasis Berbasis Keluarga," Pancaran, vol. 5, no. 1, pp. 55-66, 2016.

[7] D. Kuswanto, Statistik untuk Pemula \& Orang Awam. Jakarta: Laskar Aksara, 2012.

[8] Sugiyono, Metode penelitian pendidikan:(pendekatan kuantitatif, kualitatif dan $R \& D$ ). Bandung: Alfabeta, 2008.

[9] R. Sundayana, Statistika Penelitian Pendidikan. Bandung: Alfabeta, 2014.

[10] S. Arikunto, Prosedur Penelitian Suatu Pendekatan Praktek. Jakarta: Rineka Cipta, 2014.

[11] Sugiyono, Kualitatif, dan Kombinasi (Mixed Methods). Bandung: Alfabeta, 2013.

[12] E. N. Azyura and Mulyani, "Pengaruh Media Scrapbook Terhadap Hasil Belajar IPS Tema 7 Indahnya Keragaman di Negeriku Kelas IV," JPGSD, vol. 6, no. 8, pp. 1417-1426, 2018.

[13] D. Sudjana, Manajemen Program Pendidikan. Bandung: Falah Production, 2009.

[14] R. Riyani, S. Maizora, and Hanifah, "Uji Validalitas Pengembangan Tes untuk Mengukur Kemampuan Pemahaman Relasional pada Materi Persamaan Kuadrat Siswa Kelas VIII SMP," J. Penelit. Pembelajaran Mat. Sekol., vol. 1, no. 1, pp. 60-65, 2017.

[15] A. Rahmat and E. Mamonto, "Pengaruh Metode Bercerita terhadap Kemampuan Menyimak Anak di Kota Solo Gorontalo," J. Nonform. Educ. Community Empower., vol. 5, no. 1, pp. 9-15, 2016.

[16] N. Dhieni, L. Fridani, A. Muis, and G. Yarmi, Metode Pengembangan Bahasa. Jakarta: Universitas Terbuka, 2014. 